\title{
PENGARUH MULTI NUTRIENT SAUCE (MNS) DENGAN DOSIS YANG BERBEDA DALAM RANSUM TERHADAP KECERNAAN PROTEIN KASAR DAN SERAT KASAR PADA DOMBA
}

\section{The Effect of Multi Nutrient Sauce (MNS) With Different Dosis in Rations to the Digestibility of Crude Protein and Crude Fiber in Sheep}

\author{
M Alvin Rifqi Fadilla, Erwanto, Muhtarudin, dan Agung Kusuma Wijaya \\ Department of Animal Husbandry, Faculty of Agriculture Lampung University \\ Soemantri Brodjonegoro No. 1 Gedung Meneng Bandar Lampung 35145 \\ e-mail: muhammad.alvin354@gmail.com
}

\begin{abstract}
The purpose of this research was to determine the effect of addition of Multinutrient Sauce (MNS) in the ration on digestibility of crude protein and crude fiber in sheep. This research was conducted in May-July 2019 at the People's Farm of Kebagusan Village, Gedong Tataan District, Pesawaran Regency. The digestibility analysis of crude protein and crude fiber was carried out at the Laboratory of Animal Nutrition and Feed, Animal Husbandry Department, Faculty of Agriculture, University of Lampung. This study used a randomized block design (RBD) based on sheep body weight with six groups and three treatments, namely R0 (ration without MNS); R1 (R0 + MNS 5\%); and R2 (R0 + MNS 10\%). The data obtained were analyzed using ANOVA at a 5\% significance level or 1\% significance, and continued with further test using Least Significant Difference Test (LSD) if there is significant results. The results showed that the addition of $10 \%$ MNS in the ration had a significant effect $(\mathrm{P}<0.05)$ on increasing the digestibility of crude protein and crude fiber in sheep.
\end{abstract}

Keywords: multi nutrient sauce (MNS), digestibility of crude protein, digestibility of crude fiber, sheep

\begin{abstract}
ABSTRAK
Penelitian ini bertujuan untuk mengetahui pengaruh penambahan Multi Nutrient Sauce (MNS) dalam ransum terhadap kecernaaan protein kasar dan serat kasar pada domba. Penelitian ini dilaksanakan pada Mei-Juli 2019 di Peternakan Rakyat Desa Kebagusan, Kecamatan Gedong Tataan, Pesawaran. Analisis kecernaan protein kasar dan serat kasar dilakukan di Laboratorium Nutrisi dan Makanan Ternak, Jurusan Peternakan, Fakultas Pertanian, Universitas Lampung. Penelitian ini menggunakan Rancangan Acak Kelompok (RAK) berdasarkan bobot badan domba dengan enam kelompok dan tiga perlakuan yaitu R0 (ransum tanpa MNS); R1 (R0 + MNS 5\%); dan R2 (R0 + MNS 10\%). Data hasil penelitian dianalisis menggunakan ANOVA pada taraf nyata $5 \%$ atau sangat nyata $1 \%$, hasil analisis berbeda nyata diuji lanjut menggunakan Uji Beda Nyata Terkecil (BNT). Hasil penelitian menunjukkan bahwa penambahan MNS 10\% dalam ransum berpengaruh nyata $(\mathrm{P}<0,05)$ meningkatkan kecernaaan protein kasar dan serat kasar pada domba.
\end{abstract}

Kata kunci: multi nutrient sauce (MNS), kecernaan protein kasar, kecernaan serat kasar, domba 


\section{PENDAHULUAN}

Salah satu keberhasilan meningkatnya produksi domba dipengaruhi oleh faktor pakan. Pakan memiliki peran penting bagi ternak antara lain untuk pertumbuhan, mempertahankan hidup, menghasilkan produk hewani bagi ternak muda, serta menghasilkan tenaga (Kartadisastra, 1997). Pakan yang baik akan menjadikan ternak dapat melaksanakan proses metabolisme dalam tubuh secara normal, menjaga keseimbangan jaringan tubuh, dan mencukupi kebutuhan energi (Murtidjo, 1993).

Usaha memperbaiki pakan pada ternak ruminansia selain perbaikan kualitas pakan prarumen juga harus ditunjang dengan perbaikan yang mendukung bioproses di dalam rumen dan pascarumen. Bioproses di dalam rumen sangat dipengaruhi oleh mikroba di dalam rumen. Laju pertumbuhan mikroba rumen maksimum dicapai apabila pasokan semua nutrisi prekursor tersedia dalam konsentrasi yang optimum. Suplementasi atau penambahan nutrisi dibutuhkan untuk mendukung pertumbuhan mikroba di dalam rumen dalam memanfaatkan pakan yang dikonsumsi. Oleh karena itu, diperlukan pengembangan suplemen ransum bergizi tinggi yang dapat membantu meningkatkan laju pertumbuhan mikroba dalam rumen.

Multi Nutrient Sauce (MNS) merupakan salah satu suplemen nutrisi bergizi yang di dalamnya terdiri dari molases, urea, dolomit, mineral, dan vitamin. Suplemen tersebut berfungsi untuk meningkatkan palatabilitas ternak dan meningkatkan nutrisi pakan yang berkualitas rendah. Penambahan MNS diharapkan mampu mengoptimalkan populasi mikroba dalam rumen dan pascarumen serta dapat meningkatkan metabolisme zat-zat makanan lebih baik sehingga berimplikasi positif terhadap kecernaan domba.

\section{MATERI DAN METODE}

\section{Waktu dan Tempat}

Penelitian ini dilaksanakan pada Mei Juli 2019 di Peternakan Rakyat Desa Kebagusan, Kecamatan Gedong Tataan, Pesawaran. Analisis kecernaan protein kasar dan serat kasar dilakukan di Laboratorium Nutrisi dan Makanan Ternak, Jurusan Peternakan, Fakultas Pertanian, Universitas Lampung.

\section{Alat dan Bahan}

Peralatan yang digunakan adalah kandang individu dengan kapasitas 18 ekor domba lengkap dengan tempat pakan dan air minum, timbangan yang digunakan yaitu timbangan gantung kapasitas $50 \mathrm{~kg}$ dengan ketelitian $0,01 \mathrm{~kg}$ merek Nankai ${ }^{\circledR}$, timbangan digital kapasitas $10 \mathrm{~kg}$ dengan ketelitian $0,01 \mathrm{~kg}$ merek Nankai ${ }^{\circledR}$, timbangan analitik kapasitas 300 gr dengan ketelitian 0,0001 gr, drum sebagai tempat penyimpanan pakan, bak, karung plastik, tali, sekop, ember, terpal, cangkul, jaring-jaring alas pakan dan feses, plastik, termohigrometer, dan selang air. Alat yang digunakan untuk analisis proksimat yaitu satu set alat analisis proksimat di laboratorium.

Bahan yang digunakan adalah 18 ekor domba lokal jantan yang dipelihara secara intensif pada kandang individu. Ransum perlakuan (R0) berupa ransum basal (silase hijauan dan onggok) yang digunakan peternak ditambahkan multi nutrient sauce (MNS) dengan persentase yang berbeda. Bahan penyusun MNS yaitu: molases, urea, garam, dolomit, vitamin, dan mineral. Air minum (berasal dari sumur) diberikan secara ad libitum serta bahan-bahan analisis proksimat. Kandungan nutrisi masingmasing bahan pakan berdasarkan bahan kering terdapat pada Tabel 1 .

Tabel 1. Kandungan nutrisi ransum perlakuan $\mathrm{R} 0$ berdasarkan BK

\begin{tabular}{|c|c|c|c|c|c|}
\hline \multirow{2}{*}{$\begin{array}{l}\text { Bahan } \\
\text { pakan }\end{array}$} & \multicolumn{5}{|c|}{ Kandungan nutrisi } \\
\hline & BK & PK & LK & SK & Abu \\
\hline & \multicolumn{5}{|c|}{ 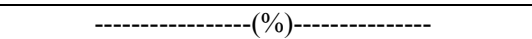 } \\
\hline Silase & 22,91 & 12,69 & 12,26 & 22,97 & 13,12 \\
\hline Onggok & 80,38 & 2,23 & 2,51 & 9,50 & 3,06 \\
\hline Jumlah & 26,93 & 12,21 & 11.58 & 22,03 & 12,42 \\
\hline
\end{tabular}

\section{Metode}

Penelitian ini menggunakan metode eksperimental dengan teknik penelitian Rancangan Acak Kelompok (RAK) meliputi tiga perlakuan yaitu R0 (Ransum basal), R1 (R0 + MNS 5\%), dan R2 (R0 + MNS 10\%). Domba dikelompokkan menjadi 6 kelompok berdasarkan kisaran bobot badan.

Adapun formulasi multi nutrient sauce (MNS) dapat dilihat pada Tabel 2 berikut.

Tabel 2. Formulasi multi nutrient sauce (MNS)

\begin{tabular}{lc}
\hline Bahan penyusun & Persentase (\%) \\
\hline Molases & 67,00 \\
Urea & 10,00 \\
Garam & 8,00 \\
Dolomit & 8,00 \\
Vitamin Mineral & 7,00 \\
\hline Jumlah & $\mathbf{1 0 0 , 0 0}$ \\
\hline
\end{tabular}

Analisis kandungan protein kasar dan serat kasar pada sampel feses maupun pakan 
menggunakan metode analisis proksimat menurut Fathul (2015).

Data yang diperoleh dianalisis dengan analisis of variance (ANOVA) pada taraf nyata $5 \%$ atau sangat nyata $1 \%$. Apabila hasil analisis ragam berpengaruh nyata $5 \%$ atau sangat nyata $1 \%$ pada satu peubah maka analisis tersebut dilanjutkan uji Beda Nyata Terkecil (BNT).

\section{HASIL DAN PEMBAHASAN}

\section{Pengaruh Penambahan Multi Nutrient Sauce (MNS) terhadap Kecernaan Protein Kasar pada Domba}

Hasil analisis ragam menunjukkan bahwa perlakuan penambahan multi nutrient sauce berpengaruh nyata $(\mathrm{P}<0,05)$ terhadap nilai kecernaan protein kasar pada domba (Tabel 3). Hasil uji lanjut memperlihatkan bahwa nilai ratarata kecernaan protein kasar domba dengan perlakuan ransum penambahan MNS 10\% (R2) lebih besar dari pada perlakuan ransum kontrol (R0) dan ransum dengan penambahan MNS 5\% (R1). Nilai rata-rata kecernaan setiap perlakuan disajikan dalam Tabel 3 berikut:

Tabel 3. Rata-rata kecernaan protein kasar pada domba

\begin{tabular}{|c|c|c|c|}
\hline \multirow{2}{*}{ Kelompok } & \multicolumn{3}{|c|}{ Perlakuan } \\
\hline & R0 & R1 & R2 \\
\hline & \multicolumn{3}{|c|}{ - } \\
\hline 1 & 59,66 & 66,13 & 61,89 \\
\hline 2 & 59,98 & 58,45 & 61,54 \\
\hline 3 & 55,22 & 61,24 & 61,08 \\
\hline 4 & 59,87 & 61,56 & 62,27 \\
\hline 5 & 55,44 & 61,87 & 63,19 \\
\hline 6 & 58,44 & 59,04 & 68,26 \\
\hline \multirow{2}{*}{ Rata-rata } & $58,10^{\mathrm{a}}$ & $61,38^{\mathrm{b}}$ & $63,04^{b}$ \\
\hline & $\pm 2,22$ & $\pm 2,72$ & $\pm 2,66$ \\
\hline
\end{tabular}

Keterangan:

huruf superskrip yang berbeda menunjukkan hasil yang berbeda nyata $(\mathrm{P}<0,05)$ berdasarkan hasil uji lanjut Beda Nyata Terkecil (BNT)

$$
\begin{array}{ll}
\text { R0 } & \text { : ransum tanpa MNS } \\
\text { R1 } & \text { : R0 + MNS5\% } \\
\text { R2 } & \text { : R0 }+ \text { MNS10\% }
\end{array}
$$

Berdasarkan hasil analisis laboratorium diketahui bahwa kandungan protein kasar dalam ransum penelitian dengan perlakuan R0 sebesar 12, 21\% (Tabel 1) tetapi berdasarkan tabel NRC (1985) terlihat bahwa kebutuhan protein domba jantan dengan bobot 10 - $20 \mathrm{~kg}$ sebesar 10,63 $14,13 \%$ sehingga berdasarkan data tersebut maka kandungan protein ransum penelitian ini telah mencukupi dari minimal standar kebutuhan domba. Rata-rata kecernaan protein kasar ransum pada domba yang mendapat perlakuan
R0, R1, dan R2 masing-masing 58,10\%; 61,38\% dan 63,04\%. Nilai kecernaan protein kasar meningkat seiring dengan meningkatnya penambahan MNS dalam ransum. Hal ini berarti penambahan MNS dalam ransum dapat meningkatkan kecernaan protein kasar pada domba perlakuan.

Penambahan MNS dalam ransum yang merupakan suplemen nutrisi bergizi yang di dalamnya merupakan perpaduan antara urea sebagai sumber $\mathrm{N}$ dan molases sebagai sumber energi yang mana MNS juga mengandung berbagai unsur-unsur mikro seperti vitamin dan mineral yang membantu meningkatkan produktivitas ternak. Kartadisastra (1997) menjelaskan bahwa penambahan ransum suplemen dapat memacu pertumbuhan dan meningkatkan populasi mikroba di dalam rumen. Sejalan dengan pendapat Putra (1999) yang menyatakan bahwa penambahan suplemen dalam ransum dapat meningkatkan aktivitas mikroba rumen, sintesis protein mikroba, kecernaan bahan kering ransum, dan pertambahan bobot hidup ternak.

Ransum yang digunakan pada penelitian ini merupakan campuran antara silase hijauan dan onggok. Walker and Kohler (1981) menyatakan bahwa kualitas pakan hijauan yang rendah ditandai dengan tingginya kandungan lignoselulosa dan rendahnya kadar nitrogen. Sebagai akibatnya, pakan tersebut menjadi sedikit dicerna, rendahnya palatabilitas, dan pemanfaatan unsur hara yang jelek sehingga sering kali tidak dapat memenuhi kebutuhan nutrisi ternak ruminansia.

Hasil analisis ragam menunjukkan bahwa perbedaan nyata disebabkan karena adanya molases di dalam bahan penyusun MNS. Molases merupakan sumber energi bagi bakteri asam laktat. Bakteri asam laktat sendiri bekerja untuk membantu meningkatkan kecernaan protein kasar di dalam rumen. Molases merupakan karbohidrat fermentable yang digunakan sebagai energi bagi pertumbuhan bakteri pembentuk asam laktat dan asam laktat yang dihasilkan bereaksi dengan amonia atau NH3 (Migo et al., 1993).

Selain itu bakteri asam laktat juga bekerja memfiksasi NH3 sebagai sumber $\mathrm{N}$ untuk perkembangbiakannya. Hal ini sesuai dengan pendapat Nurul et al. (2012) yang menyatakan bahwa yang penting dari bakteri asam laktat adalah kemampuannya untuk memfermentasi gula menjadi asam laktat (Lactobacillus lactis, Pediococcus, Streptococcus, dan Acetobacter aceti) dimana bakteri tersebut merupakan penyumbang protein asal mikrobia. 
Perlakuan yang berbeda nyata antar perlakuan diduga karena adanya urea di dalam MNS. Penggunaan urea dalam bahan penyusun MNS dimaksudkan untuk membantu meningkatkan kualitas pakan dan meningkatkan fermentasi di dalam rumen. Sebagian besar bakteri rumen menggunakan amonia sebagai sumber $\mathrm{N}$ mereka untuk pertumbuhan. Berdasarkan penelitian Bach et al. (2005) yang menyatakan bahwa sekitar $80 \%$ sel mikroba $\mathrm{N}$ berasal dari amonia.

Kemampuan ternak ruminansia yang mampu memperoleh sumber protein dengan cara memanfaatkan semua senyawa nitrogen di dalam rumen. Kemampuan tersebut berkaitan dengan adanya mikroorganisme dalam rumen yang menggunakan amonia untuk pertumbuhan dan pada akhirnya menghasilkan protein mikroba sebagai sumber protein ruminansia (Gulinski et al., 2016). Urea dalam rumen akan cepat dihidrolisis dan dimetabolisme oleh enzim urease menjadi amonia dan $\mathrm{CO} 2$ yang kemudian meningkatan konsentrasi amonia dalam rumen (Puga et al., 2001).

McDonald et al. (2002) menyatakan bahwa protein ransum dalam rumen akan dirombak oleh mikroba menjadi NH3, karbon dioksida, dan volatile fatty acid (VFA) hal ini sesuai dengan pendapat Hungate (1966) yang menyatakan bahwa VFA merupakan sumber utama energi dan karbon untuk pertumbuhan ternak inang dan mempertahankan kehidupan mikroorganisme dalam rumen.

Jika kandungan pakan defisiensi protein atau protein tahan terhadap degradasi dalam rumen maka konsentrasi NH3 dalam rumen akan menurun dan memperlambat pertumbuhan mikroba rumen sehingga kecernaan pakan juga menurun (McDonald et al., 2002). Jumlah NH3 yang optimal dalam cairan rumen $(8,75$ $\mathrm{mgN} / 100 \mathrm{ml}$ ) dapat meningkatkan kadar VFA di dalam rumen. Penggunaan urea yang mengandung amonia dalam bahan pembuatan MNS dimanfaatkan oleh bakteri rumen untuk pertumbuhan dan memperbanyak populasi mikroba rumen.

Perlakuan lain yang menyebabkan adanya perbedaan nyata diduga adanya penambahan zat nutrisi mineral dalam bahan penyusun MNS. Pengaruh penambahan mineral dalam bahan penyusun MNS dapat mempengaruhi aktivitas metabolisme glukosa serta mempertahankan kecepatan transfer glukosa dari darah ke dalam sel (Underwood, 1977). Menurut Underwood (1977) bahwa mineral berperan sebagai pengatur transport zat makanan ke sel, mengatur permeatabilitas membran sel, dan mengatur metabolisme zat makanan. Kinerja mikroba akan semakin aktif seiring dengan meningkatnya suplai energi yang cukup akibat dari suplementasi mineral organik (Astuti et al., 2015). Suplai energi yang cukup meningkatkan aktifitas mikroba di dalam rumen. Hal ini akan memacu peningkatan kecernaan bahan pakan seperti kecernaan protein kasar oleh mikroba rumen.

Kecernaan protein kasar dalam penelitian memiliki kisaran rata-rata antara 58,10\%$63,04 \%$ (Tabel 3) dimana nilai kecernaan ini lebih rendah dibandingkan kecernaan protein kasar menurut penelitian Yulistiani (2010) yang melakukan pemberian ransum tongkol jagung dengan penambahan konsentrat berprotein tinggi pada domba memiliki rataan sebesar 78,4\%. Kecernaan protein kasar tersebut disebabkan oleh pemberian ransum hijauan yang telah mengalami fermentasi yang mana proses fermentasi menjadikan ransum bersifat asam. Penambahan MNS dalam ransum yang salah satu bahan penyusunnya adalah dolomit yang bersifat basa dapat menstabilkan kondisi $\mathrm{pH}$ di dalam rumen.

Penambahan MNS dalam ransum memacu pertumbuhan mikroba di dalam rumen. Ruminansia mendapatkan protein dari 3 sumber, yaitu protein mikroba rumen, protein pakan yang lolos dari perombakan mikroba rumen, dan sebagian kecil dari endogenus (Tillman et al., 1989). Adanya peningkatan jumlah mikroba dalam rumen menyebabkan enzim-enzim pencerna protein kasar lebih besar dan dapat memicu meningkatnya penyerapan protein kasar di dalam saluran pencernaan. Dengan meningkatnya penyerapan protein kasar di dalam rumen menyebabkan terpenuhinya kebutuhan ternak akan protein kasar.

\section{Pengaruh Penambahan Multi Nutrient Sauce (MNS) terhadap Kecernaan Serat Kasar pada Domba}

Hasil analsis ragam menujukkan bahwa penambahan MNS dalam ransum berpengaruh nyata $(\mathrm{P}<0,05)$ terhadap kecernaan serat kasar domba. Rata-rata kecernaan serat kasar domba yang diberi perlakuan R0 (ransum tanpa MNS) sebesar 44,98\% mengalami peningkatan pada perlakuan R1 (R0 + MNS 5\%) sebesar 51,52\% dan R2 (R0 + MNS 10\%) sebesar 55,48\%. Hasil uji lanjut Beda Nyata Terkecil (BNT) menunjukkan bahwa nilai rata-rata kecernaan serat kasar domba dengan perlakuan ransum penambahan MNS 10\% lebih besar $(\mathrm{P}<0,05)$ dari pada ransum dengan penambahan MNS 5\% dan perlakuan ransum kontrol. Nilai rata-rata kecernaan serat kasar pada domba dapat dilihat pada Tabel 4 berikut. 
Tabel 4. Rata-rata kecernaan serat kasar pada domba

\begin{tabular}{cccc}
\hline \multirow{2}{*}{ Kelompok } & \multicolumn{3}{c}{ Perlakuan } \\
\cline { 2 - 4 } & R0 & R1 & R2 \\
\hline & 47,41 & 52,26 & 55,14 \\
2 & 43,14 & 52,11 & 54,02 \\
3 & 44,50 & 53,45 & 55,91 \\
4 & 44,92 & 49,21 & 56,37 \\
5 & 44,72 & 50,15 & 54,68 \\
6 & 45,20 & 51,94 & 56,73 \\
\hline \multirow{2}{*}{ Rata-rata } & $44,98^{\mathrm{a}}$ & $51,52^{\mathrm{b}}$ & $55,48^{\mathrm{b}}$ \\
& $\pm 1,39$ & $\pm 1,55$ & $\pm 1,04$ \\
\hline
\end{tabular}

Keterangan:

huruf superskrip yang berbeda menunjukkan hasil yang berbeda nyata $(\mathrm{P}<0,05)$ berdasarkan hasil uji lanjut Beda Nyata Terkecil (BNT)

R0 : ransum tanpa MNS

R1 : R0 + MNS 5\%

R2 : R0 + MNS 10\%

Rata-rata nilai kecernaan serat kasar meningkat seiring dengan meningkatnya penambahan MNS dalam ransum. Hal ini disebabkan penambahan MNS dalam ransum dapat meningkatkan kecernaan serat kasar pada domba perlakuan. Nilai kecernaan yang tinggi pada suatu ransum menujukkan bahwa bahan pakan tersebut mempunyai kualitas zat makanan yang baik (Sutardi, 1980). Kecernaan pakan sangat tergantung dari peranan mikroba rumen yang menyebabkan ruminansia dapat mencerna bahan makanan yang berserat kasar tinggi. Erwanto (1995) menjelaskan bahwa kecernaan pakan serat kasar dalam rumen pada dasarnya adalah hasil kerja enzim-enzim pencernaan serat yang diproduksi oleh mikroba rumen.

Perbedaan yang nyata pada masingmasing perlakuan karena adanya penambahan MNS dalam ransum yang dapat meningkatkan kecernaan serat kasar. Meningkatnya nilai kecernaan serat kasar pada perlakuan R1(MNS $5 \%$ ) dan R2 (MNS 10\%) dibandingkan dengan perlakuan R0 menujukkan bahwa penambahan MNS dapat membantu meningkatkan nilai kecernaan serat kasar dimana serat kasar digunakan oleh ternak ruminansia sebagai sumber energi utama yang efisien dan berperan penting dalam metabolisme tubuh (Suprapto et al., 2013). Martini dan Sitompul (2005) menyatakan bahwa ruminansia dapat mencerna serat kasar dengan baik, dimana $70-80 \%$ dari total kebutuhan energinya berasal dari serat kasar.

Berdasarkan hasil penelitian kecernaan serat kasar menujukkan bahwa nilai kercernaan serat kasar perlakuan R2 (R0 + MNS10\%) menghasilkan kecernaan serat kasar lebih tinggi
$(\mathrm{P}<0,05)$ dibandingkan dengan perlakuan yang lainnya. Nilai kecernaan yang diperoleh dari penelitian ini jauh lebih tinggi jika dibandingkan dengan hasil penelitian Budiman et al. (2006) yang menunjukkan rata-rata nilai kecernaan serat kasar pada domba yang diberi ransum dengan kandungan protein $12 \%$ sebesar $38,82 \%$. Hal tersebut diduga karena nilai kecernaan tidak hanya dipengaruhi oleh kandungan nutrisi di dalam ransum, tetapi juga kandungan energi dalam ransum, imbangan kandungan nutrisi harus sesuai dengan kebutuhan ternak, jangan sampai ternak defisiensi nutrisi.

Penambahan MNS yang terbuat dari beberapa bahan penyusun yaitu molases, urea, garam, dolomit, vitamin, dan mineral berperan membantu meningkatkan aktivitas mikroba rumen yang berimplikasi positif terhadap kecernaan serat kasar di dalam rumen. Hal tersebut juga dilaporkan oleh Puastuti (2009) bahwa pada ternak ruminansia proses pencernaan di dalam rumen sangat bergantung pada populasi mikroba, aktivitas mikroba, dan jenis mikroba yang berkembang di dalam rumen. Sebab proses perombakan pakan pada dasarnya adalah kerja enzim yang dihasilkan oleh mikroba rumen.

Penambahan MNS dalam ransum juga bermanfaat meningkatkan populasi mikroba rumen. Adanya kandungan molases di dalam bahan penyusun MNS dimanfaatkan oleh mikroba rumen sebagai sumber energi bagi pertumbuhan bakteri pembentuk asam laktat. Meningkatnya energi yang mudah dicerna dan protein ransum akan menginisiasi perkembangan bakteri amilolitik dan proteolitik atau bakteri lainnya lebih luas (Budiman et al. 2006). Mikroba-mikroba tersebut akan memberikan sumbangan metabolit yang dibutuhkan bakteri selulolitik. Budiman et al. (2006) menyatakan bahwa mikroba pencerna serat bukanlah pemakan tunggal terhadap substrat serat merata, tetapi membutuhkan metabolit lain dari hasil degradasi mikroba lainnya.

Peningkatan jumlah mikroba rumen akan mempengaruhi sekresi enzim pencernaan serat kasar yang dihasilkan oleh bakteri selulolitik sehingga meningkatkan degradasi ransum berserat kasar (Hartati dan Putra, 1998). Pertumbuhan mikroba yang optimal dipengaruhi oleh kebutuhan prekursor yang harus tersedia dalam konsentrasi yang optimum di dalam rumen, sehingga semakin banyak populasi mikroba rumen dapat meningkatkan kecernaan fraksi serat kasar pada ransum yang dikonsumsi.

Tabel 4 menunjukkan bahwa kecernaan serat kasar R2 lebih tinggi jika dibandingkan dengan R0 dan menunjukkan perbedaan yang 
signifikan. Peningkatan nilai kecernaan tersebut diduga adanya penambahan mineral dalam bahan penyusun MNS yang mana fungsi utama mineral yaitu meningkatkan metabolisme glukosa serta mempertahankan kecepatan trasnport glukosa dari darah ke dalam sel. Hal ini sesuai dengan pendapat Astuti et al. (2015) yang menyatakan bahwa kinerja mikroba rumen yang semakin aktif karena suplai energi yang cukup sebagai akibat dari penambahan mineral.

Mourino et al. (2001) menjelaskan bahwa aktivitas bakteri selulolitik di dalam rumen kambing memiliki $\mathrm{pH}$ normal berkisar antara 6,8-7 sehingga optimal untuk aktivitas mikroba. Pemberian silase hijauan yang memiliki $\mathrm{pH}$ asam dapat menyebabkan aktivitas dan populasi mikroba pencerna serat kasar seperti selulolitik dan hemiselulolitik dalam rumen menurun yang berakibat pada penurunan daya cerna serat kasar. Namun, penggunaan dolomit yang bersifat basa pada bahan penyusun MNS berperan dalam keseimbanagn $\mathrm{pH}$ rumen, sehingga populasi mikroba tetap terjaga.

Penggunaan MNS dalam ransum dapat membantu merekayasa populasi mikroorganisme di dalam rumen. Hal ini berakibat meningkatnya nilai kecernaan serat kasar bahan pakan yang diberikan pada ternak ruminansia. Mikroba rumen diperlukan dalam mencerna serat kasar menjadi lebih sederhana sehingga dapat dimanfaatkan oleh mikroba rumen maupun induk semang yang berimplikasi positif terhadap kecernaan serat kasar.

\section{KESIMPULAN}

Berdasarkan hasil penelitian dan pembahasan dapat disimpulkan bahwa:

1. penambahan multi nutrient sauce (MNS) dalam ransum domba berpengaruh nyata $(\mathrm{P}<0,05)$ meningkatkan kecernaaan protein kasar dan serat kasar pada domba;

2. pemberian multi nutrient sauce (MNS) dalam ransum domba dengan kadar MNS 10\% menghasilkan kecernaaan protein kasar dan serat kasar terbaik.

\section{DAFTAR PUSTAKA}

Astuti, A., Erwanto, dan P. E. Santosa. 2015. Pengaruh cara pemberian konsentrat hijauan terhadap respon fisiologis dan peforma sapi Peranakan Simmental. Jurnal Ilmiah Peterakan Terpadu. 3(4): 201-207.

Bach, A., S. Calsamiglia, dan M. D. Stern. 2005. Nitrogen metabolism in the rumen. Journal of Dairy Science. 88: E9-E21.
Budiman, A., T. Dhalika, dan B. Ayuningsih. 2006. Uji kecernaan serat kasar dan bahan ekstrak tanpa nitrogen (BETN) dalan ransum lengkap berbasis hijauan daun pucuk tebu (Saccharum officinarum). Jurnal Ilmu Ternak. 6(2): 132-135.

Erwanto. 1995. Optimalisasi Sistem Fermentasi Melalui Suplementasi Sulfur Defaunasi, Reduksi Emisi Metan dan Stimulasi Pertumbuhan Mikroba pada Ternak Ruminansia. Disertasi. Institut Pertanian Bogor. Bogor.

Fathul, F. 2015. Penentuan Kualitas dan Kuantitas Kandungan Zat Makanan Pakan $3^{\text {rd }}$ Edition. Universitas Lampung Press. Bandar Lampung.

Guliński, P., E. Salamończyk, and K. Młynek. 2016. Improving nitrogen use efficiency of dairy cows in relation to urea in milk. Animal Science Papers and Reports. 34(1): 5-24.

Hartati, E. dan S. Putra. 1998. Suplementasi Minyak Lemuru dan Seng dalam Ransum yang Mengandung Silase Pod Coklat dan Urea untuk Memacu Pertumbuhan Sapi Holstein Jantan. Disertasi. Institut Pertanian Bogor. Bogor.

Hungate, R. E. 1966. The Rumen and Its Microbes. $2^{\text {nd }}$ Edition. Academic Press. New York.

Kartadisastra, H. R. 1997. Penyediaan dan Pengelolaan Pakan Ternak Ruminansia. Kanisius. Yogyakarta.

Martini dan S. Sitompul. 2005. Penetapan serat kasar dalam pakan ternak tanpa ekstrak lemak. Balai Penelitian Ternak. Bogor.

McDonald, P., R. A. Edwards, J. F. D. Greenhalgh, and C. A. Morgan. 2002. Animal Nutrition. $6^{\text {th }}$ Edition. Prentice Hall Eglewood Cliffs. New Jersey.

Migo, V.P., M. Matsumura, E. J .D. Rosariodan, and H. Kataoka. 1993. decolorization of molasses wastewate using inorganic flocculant. Journal of Fermentation Bioengineering. 75(6). 438-442.

Mourino, F., R. Akkarawongsa, and P. J. Weimer. 2001. Initial $\mathrm{pH}$ as a determinant of sellulose digestion rate by mixed ruminal microorganisms in vitro. Journal Dairy Science. 84: 848-859.

Murtidjo, B. A. 1993. Memelihara Domba. Kanisius, Yogyakarta.

National Research Council (NRC). 1985. Nutrient Requirement of Sheep. $6^{\text {th }}$ Edition. Revised Uni Edition. National Academy Press. Washington DC. 
Nurul, A., Junus, M., dan M. Nasich. 2012. Pengaruh penambahan molases terhadap kandungan protein kasar dan serat kasar padatan lumpur organik unit gas bio. Fakultas Peternakan Universitas Brawijaya. Malang.

Puastuti, W. 2009. Manipulasi bioproses dalam rumen untuk meningkatkan penggunaan pakan berserat. Wartazoa 19 (4). Balai Penelitian Ternak. Bogor. Pp. 180-190.

Puga, D. C., H. M. Galina, R. F. Pérez-Gil, G. L. Sanginés, B. A. Aguilera, and G. F. Haenlein. 2001. Effect of a controlled release urea supplement on rumen fermentation in sheep fed a diet of sugar cane tops (Saccharum officinarum), corn stubble (Zea mays) and King grass (Pennisetum purpureum). Small Ruminant Research. 39 (3): 269-276.

Putra, S. 1999. Peningkatan Peforma Sapi Bali melalui Perbaikan Mutu Pakan dan Suplementasi Seng (Sn) Asetat. Disertasi. Institut Pertanian Bogor. Bogor.

Suprapto, H., F. M. Suhartati, dan T. Widiyastuti. 2013. Kecernaan serat kasar dan lemak kasar complete feed limbah rami dengan sumber protein berbeda pada Kambing Pernakan Ettawa lepas sapih. Jurnal Ilmiah Peternakan. 1(3): 938-946.

Sutardi, T. 1980. Landasan Ilmu Nutrisi Jilid I. Departemen Ilmu Makanan Ternak. Intitut Pertanian Bogor. Bogor.

Tillman, A. D., S. Reksohadiprojo, S. Prawirokusumo, dan S. Lebdosoekojo. 1989. Ilmu Makanan Ternak Dasar. Gadjah Mada University Press. Yogyakarta.

Underwood, E. J. 1977. The Mineral Nutrition of Livestok $2^{\text {nd }}$ Edition. CABI. England.

Walker, H. G. and G.O. Kohler. 1981. Treated and untreated cellulosic wastes as animal feeds: Recent work in the United States of America. Journal Agriculture and Environment. 6 (2-3): 229-243.

Yulistiani, D. 2010. Amoniasi tongkol jagung (sumber serat, kecernaan $>50 \%$, pk $>6 \%$ ) dalam ransum komplit domba komposit sumatera dengan laju pertumbuhan > $125 \mathrm{~g} / \mathrm{h}$. Balai Penelitian Ternak. Ciawi. Bogor. 